IZA DP No. 9477

Where Does Education Pay Off in Sub-Saharan Africa?

Evidence from Two Cities of the Republic of Congo

Mathias Kuepié

Christophe J. Nordman

November 2015 


\title{
Where Does Education Pay Off in Sub-Saharan Africa? Evidence from Two Cities of the Republic of Congo
}

\author{
Mathias Kuepié \\ CEPS/INSTEAD and DIAL \\ Christophe J. Nordman \\ $I R D, D I A L$ and IZA
}

Discussion Paper No. 9477

November 2015

\author{
IZA \\ P.O. Box 7240 \\ 53072 Bonn \\ Germany \\ Phone: +49-228-3894-0 \\ Fax: +49-228-3894-180 \\ E-mail: iza@iza.org
}

\begin{abstract}
Any opinions expressed here are those of the author(s) and not those of IZA. Research published in this series may include views on policy, but the institute itself takes no institutional policy positions. The IZA research network is committed to the IZA Guiding Principles of Research Integrity.

The Institute for the Study of Labor (IZA) in Bonn is a local and virtual international research center and a place of communication between science, politics and business. IZA is an independent nonprofit organization supported by Deutsche Post Foundation. The center is associated with the University of Bonn and offers a stimulating research environment through its international network, workshops and conferences, data service, project support, research visits and doctoral program. IZA engages in (i) original and internationally competitive research in all fields of labor economics, (ii) development of policy concepts, and (iii) dissemination of research results and concepts to the interested public.
\end{abstract}

IZA Discussion Papers often represent preliminary work and are circulated to encourage discussion. Citation of such a paper should account for its provisional character. A revised version may be available directly from the author. 
IZA Discussion Paper No. 9477

November 2015

\title{
ABSTRACT
}

\section{Where Does Education Pay Off in Sub-Saharan Africa? Evidence from Two Cities of the Republic of Congo*}

\begin{abstract}
Using first-hand data from the 2009 Employment and Informal Sector Survey (EESIC) in the two largest cities of the Republic of Congo, Brazzaville and Pointe-Noire, we analyse the impact of education on labour market outcomes, and identify the segments where education pays off the most. Multivariate analyses of the risk of unemployment and sectoral choice indicate that young people face serious difficulties in the labour market: for most of them, their only choice is to remain unemployed or to join the informal sector. To measure the specific impact of schooling on earnings, we address issues related to sample selection and endogeneity of education in the earnings function. The results shed light on heterogeneity in the returns to schooling across the two main cities and institutional sectors. An important finding is that the informal sector does not systematically lag behind the formal sectors in terms of returns to education. We emphasize convex returns to education, meaning that the last years in secondary and tertiary schooling yield the highest returns, while those of primary education are generally lower. This convexity is also apparent in the informal sector, where education (albeit on another scale) again appears as an important determinant of earnings.
\end{abstract}

JEL Classification: J24, J31, O12

Keywords: labour market participation, unemployment, returns to education, earnings functions, informal sector, Republic of Congo

Corresponding author:

Christophe J. Nordman

IRD, DIAL

4 rue d'Enghien

75010 Paris

France

E-mail: nordman@dial.prd.fr

\footnotetext{
* The first draft of this study was commissioned by the World Bank's Poverty Reduction and Economic Management Unit (Africa Region). We wish to thank Hannah Nielsen and Monthé Bienvenu Biyoudi for their observations and suggestions on that first draft, and two anonymous referees. The authors are responsible for any potential errors or omissions therein.
} 


\section{Introduction}

In Sub-Saharan Africa, education is often viewed as the main tool to fight poverty as it can help individuals find better jobs, thereby increasing the earnings from their labour. Yet in reality, while the importance of education is emphasized as inherently related to the development and well-being of people in the region (including through the Millennium Development Goals and the Education For All initiative), its economic efficiency is more debated. It is generally recognized that the missmatch between education and employment expands as unemployment continues to grow in the cities of SubSaharan Africa, especially among educated workers (Roubaud and Torelli, 2013). This has led to a sharp increase in the number of very skilled youth who are unable to find work which matches their skills in the formal sector. This gap between the growth in investments in education and in the availability of real opportunities in the labour market creates a severe challenge for authorities. It has been known for many years that benefits available in the formal labour market (particularly in the predominant public sector) are such that it makes sense for individuals to take their place on the waiting list to enter the formal sector, without taking into consideration informal sector opportunities. In this regard, education seems to no longer protect against poverty and social exclusion in SubSaharan Africa. It is therefore essential to reassess the efficiency of investments made in schooling in these countries. In this paper, we carry out such analysis using a labour force survey data for the Republic of Congo (CNSEE, 2009).

First results of the Congolese Household Survey (CNSEE, 2006) indicate that Congolese people are relatively highly educated, with an estimated net enrollment rate of 87 percent in primary education and 44 percent in secondary education in 2005. However, this strong quantitative performance of the Congolese educational system is more nuanced when considered along with qualitative indicators: about one fourth of students enrolled in the first grade fail to reach the last year of primary education and the level of knowledge exhibited by students is very weak (CONFEMEN \& MEPSA, 2009). The structure of the Congolese labour market is largely dominated by the informal sector (78 percent), where the prevalence of poverty among workers is high ( 80 percent). The public and formal private sectors tend to protect workers much more against poverty (they include only 5 and 10 percent, respectively, of the working poor), but offer very few entry opportunities because they only represent 9 and 13 percent, respectively, of all jobs.

Given a contradictory socio-economic set-up where decent jobs in the labour market are rationed, although the economy grows at a high rate and school enrolment is comprehensive, it is particularly interesting to explore the links between educational performance, labour market entry and private economic returns to schooling at the individual level. Analysis of private returns to education is based on the standard theory of human capital, whereby earnings gaps among individuals are the result of differentials in compensation which depend on the level of workers' human capital. It is therefore 
likely that investments in education explain the distribution of individual earnings. This assumption has important consequences for poor countries, as it justifies the presence of income gaps among individuals in the labour market. However, in most African countries, not only are markets imperfect, but the nature of work contracts and vulnerability also interferes significantly with the relationship between human capital endowment and earnings (Bocquier, Nordman and Vescovo, 2010). Specifically, it is generally recognized that four labour market categories exist in developing countries: rural, public, private formal and informal. Each of these markets has its own specificities, such as seasonality of jobs and uncertainty about demand levels, the nature of contracts, and wage and compensation patterns (Ray, 1998; Schultz, 2004). Numerous studies on the link between education and labour markets in these countries have ignored the fact that different job segments, particularly in the rural and informal sectors, can significantly impact the role played by education in shaping labour market access and earnings. Some papers on Africa acknowledge this difference across jobs and sectors and estimate the returns to education for urban and rural areas separately. Other studies estimate the returns for those in the formal wage sector or public sector separately and some do both $^{1}$.

Given these specificities, we seek here to analyse how education affects participation in urban labour markets and work compensation in the Republic of Congo. In particular, we try to identify the labour market segments where education pays off, and thus aim to shed light on heterogeneities in the returns to schooling at different levels across two main cities and institutional sectors. Using data from the first phase of the 1-2 survey (discussed in more detail in Section 2), we refine indicators typically used to assess the efficiency of education in urban labour market entry. To this end, we estimate the determinants of labour allocation across the public, formal private and informal sectors, as well as those of labour earnings, and most of all the influence of education.

This paper contributes to the literature by focusing on a country for which there is little known research with respect to the relationship between education and earnings. This could be due to data limitations in the past (see Backiny-Yetna and Wodon 2010, also on the Republic of Congo). Furthermore, in the Central Africa region, very few studies have tried to estimate the returns to education nor looked specifically at investment in education (Shapiro and Oleko, 2001, is an example for the Democratic Republic of Congo). Hence, our study of the region provides a useful perspective given the previously documented heterogeneity in the estimated impact of education across the Africa continent. Another contribution of this paper is to estimate the returns to schooling assuming a more flexible functional form for the relationship between earnings and education, i.e. a piece-wise linear spline function. Although using this approach is not novel, estimating the relationship between income and education in this way is more consistent with the shape of the education-earnings profile

\footnotetext{
${ }^{1}$ See, for example, Vijverberg (1993, 1995), Siphambe (2000), Jolliffe (2004), Aromolaran (2006), Oyelere (2011), Backiny-Yetna and Wodon (2010), Foltz and Gajigo (2012).
} 
in many African countries (Schultz, 2004). This approach could potentially provide more meaningful information to guide policy than simple marginal or average returns to education estimates. Finally, we also attempt to control for the usual econometric problems when estimating the private returns to schooling, i.e. endogeneity, omitted variable and selection biases.

Section 2 of this paper describes the survey carried out in the Republic of Congo and the main variables used. Section 3 introduces and discusses the results of our various analyses, and Section 4 contains our conclusions and discusses some policy options.

\section{Survey and descriptive data on individual education and earnings in the Republic of Congo}

\subsection{The 1-2 Survey in the Republic of Congo}

The 1-2-3 Survey is a system of three overlapping surveys (Razafindrakoto et al., 2009; Nordman and Roubaud, 2010) aimed at different statistical populations: individuals, production units, and households. In the Republic of Congo, the Employment and Informal Sector Survey (EESIC) is a 1-2 Survey carried out in 2009 in Brazzaville and Pointe-Noire urban centres by the National Center for Statistics and Economic Studies of the Republic of Congo (see CNSEE, 2009). The first phase of the survey covered 2,977 households (1,446 in Brazzaville and 1,531 in Pointe-Noire), thus representing a total of more than 10,000 people. An employment questionnaire was completed for all individuals older than 10 years. Within the scope of this study, we focus on people aged 15 years and older.

\subsection{Descriptive statistics on education ${ }^{2}$}

Educational levels were determined by a set of questions asked in each household member about the following: school attendance (current and past), the level of education reached, the number of completed years of schooling, qualifications obtained (contrasting general education and vocational training), the type of institution attended during the first year of schooling, as well as the level of education and employment status of the interviewee's father. Overall statistics provided in Table A1 in Appendix A indicate that educational capital accumulation is considerable: the number of schooling years completed averages about 9 years, and more than four-fifths of individuals aged 15 years and older (83 percent) completed the primary level. It must be noted that individuals aged 15 years and older seem slightly more educated in Brazzaville than in Pointe-Noire. Hence, the proportion of those with no education or incomplete primary level is higher in Pointe-Noire (20 percent in Pointe-Noire

\footnotetext{
${ }^{2}$ Descriptive statistics on all variables used in this study are provided in Table A1 in Appendix A.
} 
vs. 16 percent in Brazzaville); conversely, the number of individuals who went on to pursue higher education studies is higher in Brazzaville (13 percent vs. 9 percent).

Women are clearly at a disadvantage ${ }^{3}$ : over 20 percent of women did not complete primary school (vs. 13 percent of men) - this percentage reaches 24 percent in Pointe-Noire. One last point must be made about the educational landscape: little weight is given to vocational training, which never exceeds 8 percent among those older than 15 years of age $(8$ percent in Brazzaville and 6 percent in Pointe-Noire). This means that the educational system focuses more on general education than on technical and vocational training.

\subsection{Descriptive statistics on individual earnings}

Generally, analysing compensation in Africa is a challenge, because most workers are employed in the agriculture or informal sectors, where accounting or payroll records are absent and individuals are naturally reluctant to state their income (this is the case outside Africa as well). Employment surveys such as 1-2-3 provide estimates for all monetary and non-monetary benefits related to employment (various bonuses, paid leave, housing, in-kind services, etc.) which supplement basic income.

Table 1 Average Income from Main Activity (Age 15 years and above, in thousands of monthly CFAF)

\begin{tabular}{l|c|c|c|c}
\hline & $\begin{array}{c}\text { Public } \\
\text { Sector }\end{array}$ & $\begin{array}{c}\text { Formal } \\
\text { Private } \\
\text { Sector }\end{array}$ & $\begin{array}{c}\text { Informal } \\
\text { Sector }\end{array}$ & Total \\
\hline Brazzaville & 130.3 & 131.8 & 76.0 & 97.8 \\
Pointe-Noire & 133.4 & 156.8 & 81.0 & 98.0 \\
\hline Total & 130.9 & 143.5 & 78.1 & 97.9 \\
\hline
\end{tabular}

Source: Enquête sur l'Emploi et le Secteur Informel au Congo (EESIC) 2009, Republic of Congo; authors' calculations.

However, as is typical in this kind of survey, measurement errors increase when dealing with nonwage earners, especially in the informal sector. ${ }^{4}$ To overcome these constraints, at least partially, two strategies were developed (see the interviewer manual, CNSEE, 2009): firstly, interviewers had to help non-wage earners (independent workers and employers) retrace their income by pulling together their cash inflow and their expenses over a given period of time. At the end of this process, the cash inflow received by non-wage earners is converted into a monthly basis in the questionnaire. Secondly, individuals who were unable or refused to state their specific compensation were asked to place themselves in a range or bracket, among six categories submitted to them which were defined as multiples of the statutory minimum wage. With these two strategies, it was then possible to estimate almost everyone's income. Indeed, only 5 out of 3,261 working-age individuals gave no indication at all of their level of compensation. About 6 percent (190 individuals) identified a bracket. For these,

\footnotetext{
${ }^{3}$ Statistics not included but are available on request.

${ }^{4}$ Following the ILO definition, this sector includes here all production units lacking a tax or statistical ID or without a formal accounting system.
} 
income was estimated at the bracket's mid-level (see Kuépié and Nordman, 2011 for further details). To calculate hourly earnings, this (net) monthly income was divided by the number of hours worked each month. Overall earnings data show that the average monthly income from labour reaches FCFA 98,000 (€149 in 2010) for people aged 15 years and older in Brazzaville and Pointe-Noire (see Table 1). So there are no gaps in compensation between the cities when considering all workers. In contrast, when broken down by sector, the data indicate that compensation is significantly higher in Pointe-Noire's formal private sector (€239 per month vs. €200 in Brazzaville). Differentials in earnings are particularly pronounced across sectors: for example, in the formal private sector, workers earn on average CFAF 143,000 (€218) a month, approximately 1.8 times more than those in the informal sector, who are paid only CFAF 78,000 (€119) a month. Public sector employees are also better paid, receiving CFAF 131,000 (€199) a month. This bipolar pattern is apparent in both cities under study: high compensation levels in the formal private sector (particularly in Pointe-Noire), closely followed by the public sector, with the informal sector lagging far behind.

\section{Impact of education on labour market entry and earnings}

In this study, our methodological approach aims to estimate various econometric models in order to assess the effect of diverse educational dimensions (number of years of school attendance, type of schools attended, i.e. general studies or vocational training, and degrees received) on: (i) circumstances of labour market entry (participation and choice of sector); and (ii) individual earnings resulting from the main work activity.

Incomes are estimated by applying a Mincer-type earnings model, taking into account the effect of sample selection on individuals' participation and sector choice. In addition, the data allow us to address the issue of potential endogeneity of the education variable in the earnings function through several techniques which use information on the family background of compensated workers. Econometric methods employed, as well as methodological discussions, are reported in Appendix B as they are now standard techniques.

In the first sub-section below, we provide data on the link between labour market insertion (employment, sector choice) and education. In the second sub-section, we give overall and sectoral earnings function results, and we examine synthetic results obtained from applying the various econometric methodologies discussed in Appendix B, particularly selectivity-adjusted earnings functions, and the education variable used as an endogenous explanatory variable. Finally, in the third sub-section, we focus on comparing the two cities on the basis of a set of estimates deemed most reliable for each city and sector. 


\subsection{Education, unemployment and labour market entry}

The aim of this sub-section is to briefly observe the efficiency of education in terms of exit from unemployment and entry into different segments of the labour market (formal/informal) ${ }^{5}$. Results from a logit model of the probability of unemployment (Table A2 in Appendix A), taking into consideration characteristics of both individuals and households - such as age, gender and migration status — show that, all else being equal, individuals who did not reach the minimum education level seem less likely to be unemployed than those who have completed at least junior high school, and even less so than those who attended university, which probably reflects lower expectations of finding better jobs within the least educated group. The more educated individuals are, the higher their expectations. So it may appear rational for them to stay unemployed for a longer duration in order to search for better jobs. Controlling for all variables, the risk of unemployment among youth remains high. This result may reflect specific difficulties faced by young people in integrating into the labour market. In a second step, we match individuals' level of education with the quality of employment, which we proxy using the sector of activity (formal public sector, formal and informal private sectors). Using a multinomial logit model to measure the net effect ${ }^{6}$ of education on distribution across sectors (see Table A3 in Appendix A), we show that, in each city, more education always tends to favour employment in the public sector and decreases work in the informal sector. There is no significant effect of education on access to the formal private sector. This finding could reflect the inability of formal private sector businesses to create highly skilled jobs for young university graduates. As for unemployment, young people (between the ages of 15 and 29) find it more challenging to access the public sector than those aged 30-49, and even more so than those over the age of 50 . Their only remaining option is the informal sector, where they are over-represented. This situation highlights the bottlenecks present in the Congolese civil service. While it used to be a natural opportunity for graduates, the civil service now proves unable to satisfy an increased demand for jobs from youth seeking to enter the labour market. The informal sector becomes their last refuge.

Women's situation in the labour market is worse than men's: all else remaining equal, while they face the same risk of unemployment as men, the probability that women will find formal employment is nevertheless lower in both the public and the formal private sectors. This under-representation of women in the most rewarding sectors could reflect either straightforward gender discrimination within the labour market, or a rational choice on their part to join the informal sector, assuming this sector makes it easier for women to reconcile their work and family lives (Kouamé, 1999; Nordman et al., 2011).

\footnotetext{
${ }^{5}$ Further statistics unemployment and earnings across education levels are available in Kuépié and Nordman (2011).

${ }^{6}$ We use the same set of control variables that was used to analyse unemployment.
} 


\subsection{The impact of education on labour market earnings}

\subsubsection{Specifications of earnings functions}

Regression estimates rely on the hourly, rather than monthly, log earnings, in order to take into account the heterogeneity of work duration in the various sectors. In addition to the educational level, we include migration status, family status, religion, seniority in the main job, potential experience, gender and dummy variables representing the employment sector of each person in the pooled sectoral regressions (taking as reference the informal sector) ${ }^{8}$.

In most studies, log earnings are assumed to follow a linear or quadratic relation with the number of years of schooling. Because we seek here to establish the shape of the overall earnings-schooling profile, we adopt a more flexible approach by identifying education as a piece-wise linear spline function where the strength of the relation between education and earnings varies at different parts of the education distribution. More specifically, we make a distinction between four levels: primary education, secondary 1 (junior high school), secondary 2 (senior high school) and higher education. Education-related variables introduced then become $s_{k}(e)$, where $e$ is the number of years of schooling completed at levels $k(k: 1 \ldots 4)$ :

$$
\begin{array}{cc}
S_{1}(e)= \begin{cases}e & e \leq 6 \\
6 & e>6,\end{cases} & S_{2}(e)=\left\{\begin{array}{cc}
0 & e \leq 6 \\
e-6 & 6<e \leq 10 \\
4 & e>10,
\end{array}\right. \\
S_{3}(e)=\left\{\begin{array}{cc}
0 & e \leq 10 \\
e-10 & 10<e \leq 13 \\
3 & e>13,
\end{array} S_{4}(e)=\left\{\begin{array}{cc}
0 & e \leq 13 \\
e-13 & e>13 .
\end{array}\right.\right.
\end{array}
$$

Table A4 (in Appendix A) provides estimates of earnings functions in the various sectors calculated by using the two-step Heckman method, and an endogenous education variable through the control function (CF) method (see Appendix B), where applicable. By using only one model which includes all compensated workers, it is possible simply to observe the average effect of education on earnings resulting from specific effects prevalent in each employment sector. When these effects remain similar across sectors, an overall model is enough to draw conclusions which can be applied to each segment of the labour market. Conversely, when these effects vary greatly, estimating education returns separately for each sector becomes essential.

These estimates, corrected for potential endogenous sector selection bias (by applying the Lee method), are provided in Tables A5, A6 and A7 in Appendix A. Since we use a set of other estimation

\footnotetext{
7 Potential experience is calculated as age minus years of education minus six, which is the age of school entry.

${ }^{8}$ See details at the bottom of Table A4 in Appendix A. In the informal sector, other factors not included in our equation, such as the level of physical capital among independent workers, are also likely to have a significant impact on compensation. In this study, given that we are interested in comparing the public with the private and informal sectors, we refrain from introducing enterprise-level variables in order to preserve the possibility of comparison of the estimates, and also the sample sizes.
} 
techniques recommended in Appendix B, we also provide in Table A8 a synthesis of marginal education returns obtained through the various possible methods. Before commenting on education returns, let us first analyse results obtained through the various estimation strategies.

\subsubsection{OLS vs. selectivity adjusted earnings functions}

Based on the total population of compensated workers in the three sectors, Table A4 indicates that the corrective term for the selection bias resulting from a probit equation of participation in the compensated employment becomes significant at the 5 percent threshold in Pointe-Noire. For this city, this means that the assigning mechanism in each category (participating and not participating in compensated employment) is not random and has a significant effect on earnings. Participation in paid employment is linked to unobserved characteristics which are positively correlated to earnings. Unless sample selectivity is considered, the OLS method would lead to biased estimates of the returns to observed characteristics, including human capital. On the other hand, when observing sectoral estimates (Tables A5 through A7 in Appendix A), the results show no significant selectivity term, except in Pointe-Noire's informal sector. Participation in paid employment in Pointe-Noire's informal sector is therefore linked to unobserved characteristics which are now negatively correlated to earnings.

\subsubsection{Endogenous education}

For a diagnosis of education endogeneity, we use the father's characteristics as instruments (three education levels and two socio-professional categories when the worker was 15 years old; see Table A1 in Appendix A for the definition and desriptive statistics of these variables) with the control function method (for further discussion, see Section B.2 in Appendix B). Based on first-step regressions, where we regress education on all exogenous variables, we test the joint significance of coefficients assigned to the father's characteristics, a necessary condition to keep estimates consistent. For both cities, we can confidently reject the assumption that the coefficients jointly equal zero. Given that we have more than one instrument for the endogeneous education variable, we can conduct Sargan's over-identification test. This test rejects the null hypothesis at the 10 percent level in 3 out of 8 cases, as the entire 8 cases give estimates for each city, multiplied by 4 sector cases (all sectors, public, private formal and informal). The three cases where validity is not confirmed are the full sample estimate for Brazzaville, the formal private sector estimate for Pointe-Noire and the informal sector for Brazzaville. In these cases, the tests suggest that it would be preferable to consider uncorrected education returns. ${ }^{9}$

\footnotetext{
${ }^{9}$ These tests are not included here but are available on request.
} 
When the instrument validity is not rejected, we can identify the direct correlation between the endogenous variable (education) and its unobserved determinants. If the estimate of the control variable parameter (residual from the education regression) is significant, this means that the unexplained shift in the education variable also affects the shift in earnings. Conversely, if the parameter is insignificant, we must then reject the endogeneity hypothesis. Table 2 provides values for $p$ ( $p$-value $)$ for the $t$ tests related to each control variable in the various specifications.

\section{Table 2 Endogeneity Tests for Education in Earnings Functions, where the validity of the instruments is not rejected by Sargan's over-identification tests}

\begin{tabular}{l|c|c|c|c}
\hline & $\begin{array}{c}\text { All } \\
\text { Sectors }\end{array}$ & $\begin{array}{c}\text { Public } \\
\text { Sector }\end{array}$ & $\begin{array}{c}\text { Formal } \\
\text { Private } \\
\text { Sector }\end{array}$ & $\begin{array}{c}\text { Informal } \\
\text { Sector }\end{array}$ \\
\hline $\begin{array}{l}\text { Education is } \\
\text { endogenous in the } \\
\text { earnings function }\end{array}$ & $p$ values & $p$ values & $p$ values & p values \\
\hline $\begin{array}{l}\text { Brazzaville } \\
\text { Pointe-Noire }\end{array}$ & 0.07 & 0.72 & 0.59 & 0.80 \\
\hline
\end{tabular}

Note: It is important to emphasize that these tests are meaningful only when the instruments are shown to be valid using overidentification tests (see the discussion above).

Based on these results, education endogeneity profiles of each city are quite different. In Brazzaville, the exogenous nature of the education variable cannot be rejected in the formal sectors (public and private) at the usual 10 percent threshold. In Pointe-Noire, exogeneity of education cannot be rejected in the informal sector. All in all, this analysis shows that even when instruments are assumed to be valid, conditional on observed control variables, endogeneity biases are not systematic.

In this study, when the over-identification tests do not lead to a rejection of our instruments, we put more confidence in the IV estimates, at least those using the control function method, for two reasons. Firstly, the control function method is more robust than 2SLS when slope parameters potentially vary with the unobserved factors of the model, i.e. when the variable that is supposed to be endogenous has non-linear effects, which is the case here (Card, 2001). Furthermore, we anticipate that the number of years of schooling stated by individuals could be tainted by some measurement errors due to a large proportion of stated mid-year drop-outs or class repetition in Africa (UNESCO/Breda 2007). For this reason, it seems better to use an IV estimator. In all regression results and tables analyzed below, we therefore comment on estimates corrected for endogeneity, when the instrumentation is plausible (i.e. when the over-identifcation tests do not cast doubt on the instruments); this is the case for Brazzaville's public sector and private sector; for Pointe-Noire pooled sectors, public sector and informal sector. In all other cases (i.e. pooled sectors for Brazzaville, 
the formal private sector for Pointe-Noire and the informal sector for Brazzaville), we rely on exogenous education variables ${ }^{10}$.

\subsection{Sector comparison across cities}

Figure 1 below provides histograms of marginal education returns by sector and city, at the sample's average schooling level. Estimates show that, in Pointe-Noire, education is more valued in the public sector, with a marginal return above 18 percent, and very much less valued in the other two sectors (formal private and informal). In the case of Brazzaville, however, it is in the formal private sector that the return to education is highest (10 percent), followed very closely, and surprisingly, by the informal sector ( 9 percent). Conversely, the public sector ( 7 percent) falls behind the other two sectors.

\section{[Insert Figure 1 from Appendix $A$ bere]}

\subsubsection{Convexity of returns}

In Figure 2, we show the trend of predicted earnings in each sector, based on the number of completed years of schooling. In all these sectors, we observe that earnings remain constant until about the $8^{\text {th }}$ year of schooling, after which they start to increase faster. This overall pattern can be applied to each sector, albeit with slight changes. Convexity thus intervenes later for informal sector workers (around the $12^{\text {th }}$ year of schooling). Based on these findings, the convex shape is, to a large extent, caused by the sharp increase in earnings which takes place when individuals complete higher education and start university, and mostly when informal sector workers complete their high school education.

\section{[Insert Figure 2 of Appendix A bere]}

These results contradict the conventional human capital accumulation model, where marginal education returns are assumed to remain constant, or even decrease. This convexity is now regularly observed, first by Schultz (2004) whose work is based on household surveys carried out in six African countries (South Africa, Burkina Faso, Côte d'Ivoire, Ghana, Kenya, Nigeria), by Söderbom et al. (2006) using samples of wage-earners from manufacturing companies in Kenya and Tanzania, and by Kuépié et al. (2009) and Dimova et al. (2010) who all exploited the 1-2-3 Surveys in several economic capitals of West Africa.

This result is meaningful. Indeed, according to some authors, unless the high proportion of informal sector workers is taken into consideration, returns to primary schooling could be overestimated, while higher education returns are simultaneously underestimated (Bennell, 1996). In this situation, convexity is highlighted for all sectors, including informal activities.

\footnotetext{
10 Selectivity continues to be taken into consideration in all cases. It must be noted, however, that the use of OLS for all sectors and cities does not alter this paper's main findings.
} 


\subsubsection{Return differentials across sexes and cohorts}

When estimating the order of magnitude of education returns using merged samples of men and women aged 15 years and older, we rely on two important, and potentially restrictive, assumptions.

Firstly, by merging the data for both sexes, we assume that the returns to individual characteristics are identical for men and women. This can be problematic, as women's participation in the labour market often shows less continuity than men's, especially in Africa; as a result, women may make a different use of their human capital in this market.

Therefore, we need to confirm that human capital compensation is different for each gender by estimating earnings functions using a set of interactions with the sex dummy so that the specification matches separate earnings functions. Results from this exercise are provided in Table A9 in Appendix A. In the case of education, the assertion that the education-gender cross-effects are null cannot be rejected. Therefore, these tests and estimates largely corroborate the hypothesis of the same effects for both genders (pooling assumption).

Two explanations come to mind for the similarity between each gender's returns: firstly, our samples are representative of urban areas, where gender differentials in the labour market are probably less apparent than in rural areas (Nordman et al., 2011). Secondly, the decrease in marginal education returns at all educational levels was suggested by Schultz (2002) to explain the higher returns for women, since women tend to be less educated than men on average, and higher returns were often noted for lower educational levels. However, the convexity of marginal returns highlighted here is now likely to serve as a counterweight.

As regards cohorts, we face the same issue as for gender and use the same approach as above by estimating cross-effect earnings functions using a dummy variable which indicates whether the person is older than 30 years (SENIOR). We perform a joint significance $\mathrm{F}$ test for coefficients of the interaction education-SENIOR, and provide the results in Table A10 in Appendix A.

For the public sector, the tests reject the hypothesis that education cross-terms jointly equal zero in Brazzaville's public sector, whereas for the private formal and informal sectors, this hypothesis cannot be rejected at the usual threshold. Therefore, the pooling effect assumption for these two cohorts does not appear to be very strong, at least for education.

Based on the interaction terms, it is interesting to note that higher education returns are always larger for young people (interaction coefficients are generally negative at this educational level), particularly in Brazzaville's public sector. This would indicate that the convexity of the previously observed earnings-education profile is sharper for young workers than for those who are older. Therefore, the young generation of workers would benefit most from increasing returns to the level of education. 
However, we should note that this pattern is less obvious in the private sectors (particularly in PointeNoire).

\section{Conclusion}

This study sought to analyse the impact of education on labour market outcomes, particularly earnings in the two largest cities of the Republic of Congo. To perform these analyses, we used firsthand data from Congo's 2009 Employment and Informal Sector Survey (EESIC). As far as Brazzaville and Pointe-Noire labour markets are concerned, their characteristics are similar to those of other African cities: an oversized informal sector (where more than 6 out of 10 working-age people are working) which could potentially turn into a poverty trap, and a high level of unemployment (especially among youth) which increases with the level of education. But the Congolese urban labour market is also specifically characterized by the weight of the public sector, where almost one out of three people in the capital (Brazzaville) is employed and a little over one out of five residents of both cities are employed in the public sector. Therefore, the formal private sector represents a very small share of the urban workforce.

Multivariate analyses on the risk of unemployment and sectoral choice confirm that young people suffer greatly from lack of professional employment. To measure the specific impact of education on entry into various segments of the labour market, particularly on earnings generated, one must not ignore the different self-selection biases present in various sectors of activity, nor those related to the endogeneity of education. In this study, we address these issues econometrically and make suggestions for possible corrections using information commonly available in labour force surveys in West and Central Africa. Another important methodological challenge relates to the functional shape of the link which exists between earnings and the number of years of schooling. In this study, we propose a piece-wise linear function which allows variation in the marginal return to education when graduating from one educational cycle to another.

All these methods allow us to shed light on significant heterogeneity in the returns to schooling at different levels across the two main cities and economic sectors in the Republic of Congo. With these specifications, it is also possible to emphasize the convexity of education returns; in other words, the last years in secondary and tertiary schooling generally yield the highest returns, while those of primary education are generally lower. This convexity is also apparent in the informal sector, where education is also an important determinant of earnings.

These findings are relevant to poverty alleviation policies. In order for education to lead to significantly better earnings in the labour market, and therefore to help fight monetary poverty in urban areas, it is important to expand post-primary education, including higher education. This is even 
more imperative since, in the short term, the informal sector will probably remain the main source of employment for youth wishing to enter the labour market. Yet, our results show that earnings in the informal sector increase with the number of years of schooling. For this reason, promoting postprimary and higher education, even without formal employment opportunities, can help combat poverty in the short term. Obviously, such a policy should be deployed on a parallel track to a campaign for decent work as advocated by the ILO, by extending to the informal sector social safety nets and improvements in working conditions, which are currently limited to a minority employed in the formal sector. 


\section{APPENDIX A. DESCRIPTIVE STATISTICS TABLES}

Figure 1. Marginal returns to education by sector of activity

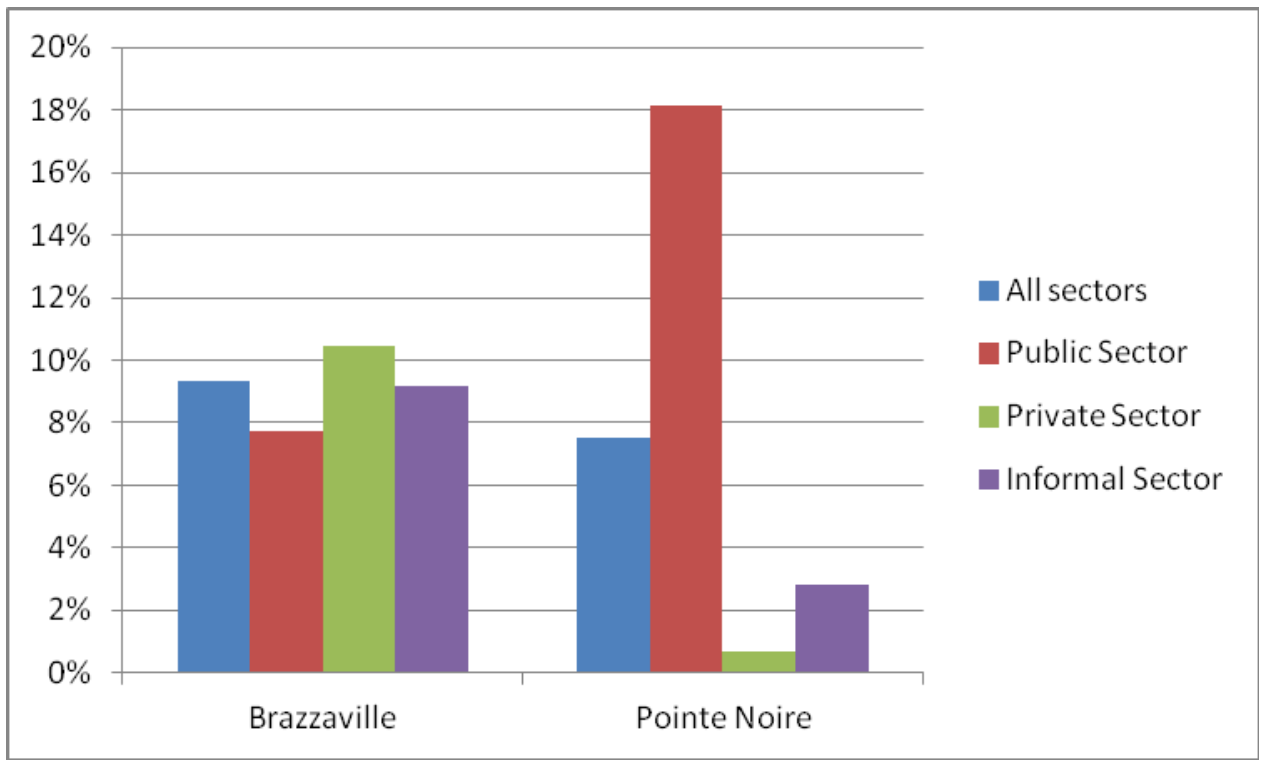

Note: These estimates stem from highlighted results reported in Table A8. The returns correspond to an endogenous or exogenous education variable depending on the results of the over-identification tests (see Appendix B). For instance, a model with an exogenous education variable is systematically preferred when the instruments appear invalid for specific sectors and cities.

Figure 2. Earnings predictions from earnings functions

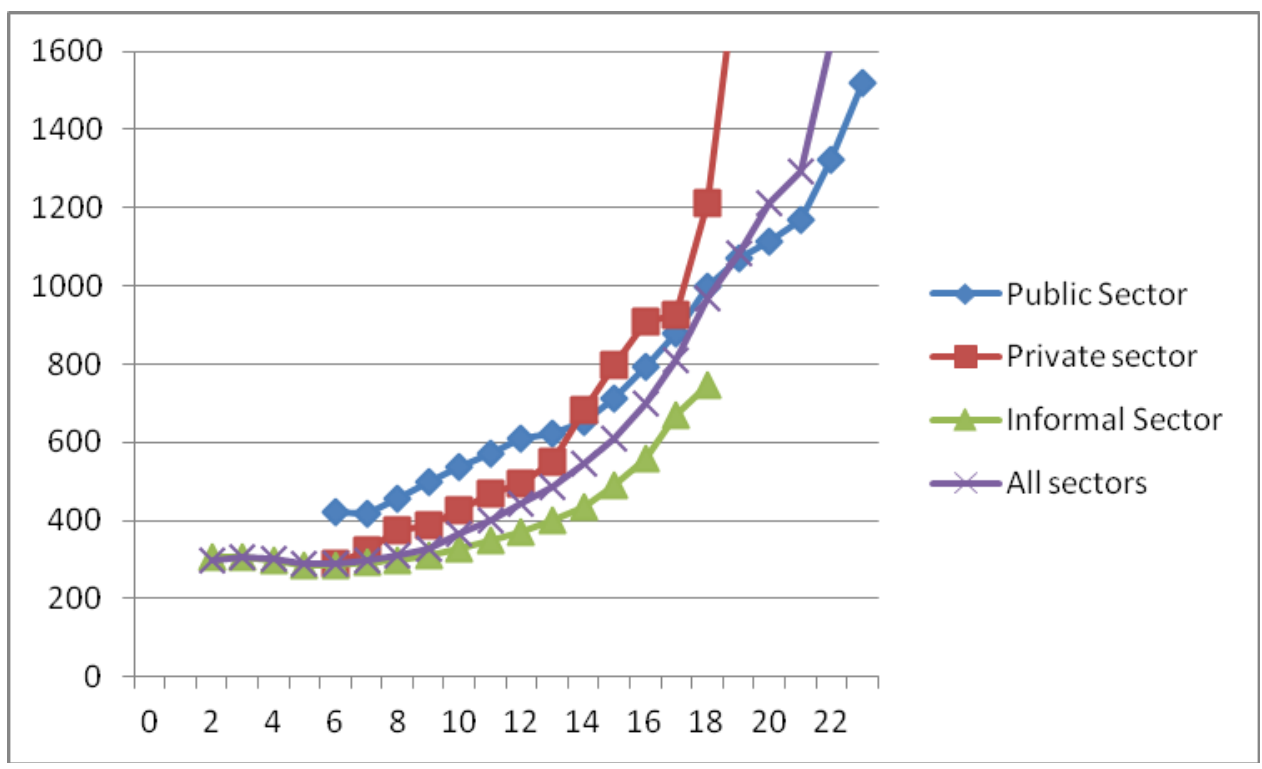

Legend: Vertical axis = hourly earnings in FCFA

Horizontal axis $=$ number of years of education achieved 
Table A1. Summary statistics of individuals (age 15 years and over) having a paid job (mean distribution of the variables used in the regressions)

\begin{tabular}{|c|c|c|c|}
\hline & Brazzaville & $\begin{array}{l}\text { Pointe- } \\
\text { Noire }\end{array}$ & Total \\
\hline Individual of Pointe-Noire & 0.00 & 1.00 & 0.37 \\
\hline Individual of Brazzaville & 1.00 & 0.00 & 0.63 \\
\hline Age & 38.32 & 35.85 & 37.41 \\
\hline $\begin{array}{l}\text { No education / Incomplete primary school } \\
\text { Completed primary school / incomplete secondary }\end{array}$ & 15.63 & 19.61 & 16.97 \\
\hline School & 35.21 & 39.57 & 36.68 \\
\hline $\begin{array}{l}\text { Vocational secondary training } \\
\text { Completed 1st level of secondary school / }\end{array}$ & 8.21 & 6.42 & 7.61 \\
\hline Incomplete 2nd level of secondary school & 21.14 & 19.50 & 20.58 \\
\hline 2nd level of secondary school completed & 6.38 & 5.99 & 6.25 \\
\hline Higher education & 13.43 & 8.92 & 11.91 \\
\hline Number of years of education & 10.31 & 9.60 & 10.05 \\
\hline Number of years of primary education & 5.77 & 5.71 & 5.75 \\
\hline Number of years of $1^{\text {st }}$ level of secondary education & 2.90 & 2.66 & 2.81 \\
\hline Number of years of $2^{\text {nd }}$ level of secondary education & 1.18 & 1.04 & 1.13 \\
\hline Number of years of higher education & 0.57 & 0.35 & 0.49 \\
\hline Potential experience & 21.65 & 19.69 & 20.93 \\
\hline Tenure in the current employment & 8.56 & 6.95 & 7.97 \\
\hline Public sector & 0.31 & 0.13 & 0.25 \\
\hline Private sector & 0.10 & 0.13 & 0.11 \\
\hline Woman & 0.40 & 0.39 & 0.39 \\
\hline Urban migrant & 0.16 & 0.29 & 0.21 \\
\hline Rural migrant & 0.16 & 0.18 & 0.17 \\
\hline Foreign migrant & 0.14 & 0.11 & 0.13 \\
\hline Married polygamous & 0.02 & 0.01 & 0.01 \\
\hline Cohabitation & 0.31 & 0.28 & 0.30 \\
\hline Single & 0.31 & 0.31 & 0.31 \\
\hline Divorced & 0.05 & 0.06 & 0.05 \\
\hline Widow & 0.03 & 0.04 & 0.04 \\
\hline Protestant & 0.13 & 0.25 & 0.17 \\
\hline Eglise de réveil & 0.26 & 0.22 & 0.25 \\
\hline Other Christian & 0.04 & 0.03 & 0.03 \\
\hline Muslim & 0.05 & 0.02 & 0.04 \\
\hline No religion & 0.07 & 0.09 & 0.08 \\
\hline Other religion & 0.03 & 0.09 & 0.06 \\
\hline Partner of the household head & 0.19 & 0.19 & 0.19 \\
\hline Son / daughter of the household head & 0.07 & 0.09 & 0.08 \\
\hline Other parent & 0.06 & 0.05 & 0.06 \\
\hline Father has between 1 to 5 years of schooling & 0.28 & 0.28 & 0.28 \\
\hline Father has between 6 to 9 years of schooling & 0.13 & 0.20 & 0.15 \\
\hline Father has between 10 to 25 years of schooling & 0.23 & 0.23 & 0.23 \\
\hline Father was wage executive & 0.22 & 0.17 & 0.20 \\
\hline Father was self-employed & 0.17 & 0.14 & 0.16 \\
\hline Unknown profession of the father & 0.38 & 0.36 & 0.37 \\
\hline
\end{tabular}


Table A2. Logit model of the probability (marginal effects) of being unemployed (age 15 years and above)

Explanatory variables

Completed primary school / Incomplete secondary school

Vocational secondary school

Completed $1^{\text {st }}$ level of secondary school / Incomplete $2^{\text {nd }}$ level of secon. school

$2^{\text {nd }}$ level of secondary school completed

Higher education

Woman

Age 15-29 years

Age 50 years and over

Rural migrant

Partner of the household head

Son / daughter of the household head

Other parent

Observations

Pseudo R-squared
Urban migrant

(1)

Brazzaville

Pointe-Noire

Note: Standard errors are in parentheses. *,** and *** mean coefficient significant at 10 percent, 5 percent and 1 percent, respectively. Other explanatory variables introduced in the models are dummies for the religion of the individuals (Catholic, Protestant, Muslim, other Christian, "eglise de réveil", no religion).

\begin{tabular}{cc}
$0.074 * *$ & 0.010 \\
$(0.037)$ & $(0.023)$ \\
$0.138^{* *}$ & $0.072^{*}$ \\
$(0.059)$ & $(0.043)$ \\
$0.123^{* * *}$ & $0.057 *$ \\
$(0.044)$ & $(0.031)$ \\
$0.111^{*}$ & 0.052 \\
$(0.061)$ & $(0.042)$ \\
$0.114 * *$ & $0.103^{* *}$ \\
$(0.048)$ & $(0.042)$ \\
-0.005 & 0.010 \\
$(0.023)$ & $(0.019)$ \\
$0.093 * * *$ & $0.075^{* * *}$ \\
$(0.022)$ & $(0.019)$ \\
$-0.104 * * *$ & -0.035 \\
$(0.023)$ & $(0.027)$ \\
0.073 & $0.160 * * *$ \\
$(0.049)$ & $(0.058)$ \\
0.042 & $0.156 * *$ \\
$(0.050)$ & $(0.068)$ \\
$0.167 * * *$ & $0.156^{* * *}$ \\
$(0.037)$ & $(0.036)$ \\
$0.181 * * *$ & $0.205^{* * *}$ \\
$(0.041)$ & $(0.041)$ \\
$0.139 * * *$ & $0.249 * * *$ \\
$(0.046)$ & $(0.046)$ \\
1,892 & 2,079 \\
0.118 & 0.115 \\
\hline percent and percent, & respectively. Other \\
& \\
& \\
&
\end{tabular}


Table A3. Impact of education on sector allocation (multinomial logit models, marginal effects)

\begin{tabular}{|c|c|c|c|c|c|c|}
\hline & \multicolumn{3}{|c|}{ Brazzaville } & \multicolumn{3}{|c|}{ Pointe-Noire } \\
\hline Explanatory variables & Public & Formal private & Informal & Public & Formal private & Informal \\
\hline Completed primary school / Incomplete secondary school & $\begin{array}{c}0.081 * * * \\
(0.030)\end{array}$ & $\begin{array}{c}0.001 \\
(0.009)\end{array}$ & $\begin{array}{l}-0.033 \\
(0.024)\end{array}$ & $\begin{array}{c}0.085^{* *} \\
(0.034)\end{array}$ & $\begin{array}{c}0.017 \\
(0.014)\end{array}$ & $\begin{array}{c}-0.057 * * \\
(0.028)\end{array}$ \\
\hline Vocational secondary school & $\begin{array}{c}0.407 * * * \\
(0.084)\end{array}$ & $\begin{array}{c}0.007 \\
(0.014)\end{array}$ & $\begin{array}{c}-0.148 * * * \\
(0.026)\end{array}$ & $\begin{array}{c}0.363^{* *} \\
(0.146)\end{array}$ & $\begin{array}{l}0.015 \\
(0.026)\end{array}$ & $\begin{array}{c}-0.160^{* * *} \\
(0.055)\end{array}$ \\
\hline $\begin{array}{l}\text { Completed } 1^{\text {st }} \text { level of secondary school } / \text { Incomplete } 2^{\text {nd }} \\
\text { level of secondary school }\end{array}$ & $\begin{array}{c}0.281 \text { *** } \\
(0.058)\end{array}$ & $\begin{array}{c}0.004 \\
(0.010)\end{array}$ & $\begin{array}{c}-0.117^{* * *} \\
(0.024)\end{array}$ & $\begin{array}{c}0.228^{* *} \\
(0.091)\end{array}$ & $\begin{array}{r}0.032 \\
(0.020)\end{array}$ & $\begin{array}{c}-0.142^{* * *} \\
(0.037)\end{array}$ \\
\hline $2^{\text {nd }}$ level of secondary school completed & $\begin{array}{l}0.444 * * * \\
(0.088)\end{array}$ & $\begin{array}{l}-0.005 \\
(0.011)\end{array}$ & $\begin{array}{c}-0.182^{* * *} \\
(0.023)\end{array}$ & $\begin{array}{c}0.559 * * * \\
(0.146)\end{array}$ & $\begin{array}{c}0.066 \\
(0.046)\end{array}$ & $\begin{array}{c}-0.249 * * * \\
(0.045)\end{array}$ \\
\hline Higher education & $\begin{array}{l}0.549 * * * \\
(0.072)\end{array}$ & $\begin{array}{c}0.014 \\
(0.013)\end{array}$ & $\begin{array}{c}-0.218^{* * *} \\
(0.018)\end{array}$ & $\begin{array}{l}0.538^{* * *} \\
(0.141)\end{array}$ & $\begin{array}{c}0.038 \\
(0.033)\end{array}$ & $\begin{array}{c}-0.256^{* * *} \\
(0.041)\end{array}$ \\
\hline Woman & $\begin{array}{c}-0.024 * * \\
(0.009)\end{array}$ & $\begin{array}{c}-0.038 * * * \\
(0.009)\end{array}$ & $\begin{array}{l}-0.031 \\
(0.021)\end{array}$ & $\begin{array}{c}-0.012^{* *} \\
(0.006)\end{array}$ & $\begin{array}{c}-0.036 * * * \\
(0.011)\end{array}$ & $\begin{array}{c}-0.057 * * \\
(0.024)\end{array}$ \\
\hline Age 15-29 years & $\begin{array}{c}-0.069 * * * \\
(0.011)\end{array}$ & $\begin{array}{c}-0.018^{* * *} \\
(0.007)\end{array}$ & $\begin{array}{c}-0.104 * * * \\
(0.020)\end{array}$ & $\begin{array}{c}-0.016 * * * \\
(0.006)\end{array}$ & $\begin{array}{c}-0.025^{* * * *} \\
(0.009)\end{array}$ & $\begin{array}{c}-0.159 * * * \\
(0.022)\end{array}$ \\
\hline Age 50 years and over & $\begin{array}{c}0.013 \\
(0.010)\end{array}$ & $\begin{array}{c}-0.020 * * * \\
(0.005)\end{array}$ & $\begin{array}{c}-0.137 * * * \\
(0.019)\end{array}$ & $\begin{array}{c}0.005 \\
(0.006)\end{array}$ & $\begin{array}{l}-0.000 \\
(0.011)\end{array}$ & $\begin{array}{c}-0.249 * * * \\
(0.021)\end{array}$ \\
\hline Urban migrant & $\begin{array}{c}0.053 * * \\
(0.025)\end{array}$ & $\begin{array}{c}-0.013^{*} \\
(0.007)\end{array}$ & $\begin{array}{c}-0.126^{* * *} \\
(0.026)\end{array}$ & $\begin{array}{c}0.007 \\
(0.012)\end{array}$ & $\begin{array}{l}-0.011 \\
(0.015)\end{array}$ & $\begin{array}{c}-0.197 * * * \\
(0.035)\end{array}$ \\
\hline Rural migrant & $\begin{array}{l}0.039 * \\
(0.023)\end{array}$ & $\begin{array}{c}-0.018^{* * *} \\
(0.007)\end{array}$ & $\begin{array}{c}-0.135^{* * *} \\
(0.025)\end{array}$ & $\begin{array}{l}0.008 \\
(0.013)\end{array}$ & $\begin{array}{l}-0.011 \\
(0.015)\end{array}$ & $\begin{array}{c}-0.179 * * * \\
(0.034)\end{array}$ \\
\hline Partner of the household head & $\begin{array}{c}-0.033 * * * \\
(0.009)\end{array}$ & $\begin{array}{c}-0.022^{* * *} \\
(0.008)\end{array}$ & $\begin{array}{c}-0.136 * * * \\
(0.020)\end{array}$ & $\begin{array}{c}-0.014 * * * \\
(0.005)\end{array}$ & $\begin{array}{c}-0.032^{* * *} \\
(0.010)\end{array}$ & $\begin{array}{c}-0.192^{* * *} \\
(0.024)\end{array}$ \\
\hline Son / daughter of the household head & $\begin{array}{c}-0.059 * * * \\
(0.008)\end{array}$ & $\begin{array}{c}-0.035^{* * *} \\
(0.006)\end{array}$ & $\begin{array}{c}-0.254^{* * *} \\
(0.017)\end{array}$ & $\begin{array}{c}-0.030^{* * *} \\
(0.006)\end{array}$ & $\begin{array}{c}-0.038^{* * *} \\
(0.008)\end{array}$ & $\begin{array}{c}-0.291 * * * \\
(0.020)\end{array}$ \\
\hline Other parent & $\begin{array}{c}-0.050^{* * *} \\
(0.008)\end{array}$ & $\begin{array}{c}-0.014^{* *} \\
(0.006)\end{array}$ & $\begin{array}{c}-0.175^{* * *} \\
(0.018)\end{array}$ & $\begin{array}{c}-0.019 * * * \\
(0.005)\end{array}$ & $\begin{array}{c}-0.030^{* * *} \\
(0.009)\end{array}$ & $\begin{array}{c}-0.264^{* * *} \\
(0.021)\end{array}$ \\
\hline $\begin{array}{l}\text { Observations } \\
\text { Pseudo R-squared }\end{array}$ & & $\begin{array}{l}3,418 \\
0.207\end{array}$ & & & $\begin{array}{l}3,416 \\
0.173\end{array}$ & \\
\hline
\end{tabular}

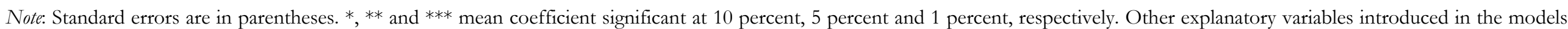
are dummies for the religion of the individuals. 
Table A4. Earnings functions with correction for selectivity into employement and for endogeneity of education when relevant

(all sectors)

Dependent variable: Log hourly earnings

\begin{tabular}{|c|c|c|}
\hline Explanatory variables & Brazzaville & Pointe-Noire \\
\hline \multicolumn{3}{|l|}{ Education variables } \\
\hline $0-6$ years (primary) & $\begin{array}{c}0.006 \\
(0.045)\end{array}$ & $\begin{array}{c}0.055 \\
(0.037)\end{array}$ \\
\hline 7-9 years (secondary 1 ) & $\begin{array}{c}0.093^{* * *} \\
(0.029)\end{array}$ & $\begin{array}{c}0.075^{* * *} \\
(0.028)\end{array}$ \\
\hline $10-13$ years (secondary 2 ) & $\begin{array}{l}0.054^{* *} \\
(0.025)\end{array}$ & $\begin{array}{c}0.142 * * * \\
(0.032)\end{array}$ \\
\hline $13+$ years (higher education) & $\begin{array}{c}0.119 * * * \\
(0.021)\end{array}$ & $\begin{array}{c}0.130^{* * *} \\
(0.033)\end{array}$ \\
\hline Potential experience & $\begin{array}{c}0.023 \\
(0.015)\end{array}$ & $\begin{array}{l}0.026^{*} \\
(0.014)\end{array}$ \\
\hline$(\text { Potential experience) })^{2} / 100$ & $\begin{array}{l}-0.018 \\
(0.027)\end{array}$ & $\begin{array}{l}-0.028 \\
(0.026)\end{array}$ \\
\hline Tenure in the current employment & $\begin{array}{l}0.019^{*} \\
(0.010)\end{array}$ & $\begin{array}{c}0.027 * * * \\
(0.009)\end{array}$ \\
\hline$(\text { Tenure in the current employment })^{2} / 100$ & $\begin{array}{l}-0.026 \\
(0.031)\end{array}$ & $\begin{array}{l}-0.051 * \\
(0.029)\end{array}$ \\
\hline Public sector & $\begin{array}{c}0.314 * * * \\
(0.067)\end{array}$ & $\begin{array}{c}0.221 * * * \\
(0.056)\end{array}$ \\
\hline Private formal sector & $\begin{array}{c}0.238^{* * * *} \\
(0.090)\end{array}$ & $\begin{array}{c}0.160^{* * *} \\
(0.061)\end{array}$ \\
\hline Woman & $\begin{array}{l}-0.134 * \\
(0.078)\end{array}$ & $\begin{array}{c}-0.319 * * * \\
(0.076)\end{array}$ \\
\hline Urban migrant & $\begin{array}{l}-0.018 \\
(0.066)\end{array}$ & $\begin{array}{c}0.027 \\
(0.053)\end{array}$ \\
\hline Rural migrant & $\begin{array}{l}-0.052 \\
(0.070)\end{array}$ & $\begin{array}{l}-0.034 \\
(0.065)\end{array}$ \\
\hline Inverse of Mill's ratio & $\begin{array}{c}0.041 \\
(0.145)\end{array}$ & $\begin{array}{c}0.296^{* *} \\
(0.136)\end{array}$ \\
\hline Education regression residuals & & $\begin{array}{l}-0.041^{*} \\
(0.023)\end{array}$ \\
\hline Constant & $\begin{array}{c}-1.875^{* * *} \\
(0.325)\end{array}$ & $\begin{array}{c}-2.225 * * * \\
(0.346)\end{array}$ \\
\hline $\begin{array}{l}\text { Observations } \\
\text { Adjusted R-squared }\end{array}$ & $\begin{array}{l}1,368 \\
0.220\end{array}$ & $\begin{array}{l}1,517 \\
0.197\end{array}$ \\
\hline
\end{tabular}

Note: Additional explanatory variables introduced in the models are dummies for family situation (single, married monogamous, married polygamous, widow, cohabitation, divorced) and for religion. Standard errors (in parentheses) are estimated using 500 bootstrap replications. *, ** and *** mean coefficient significant at 10 percent, 5 percent and 1 percent, respectively. 
Table A5. Earnings functions with correction for selectivity into sectors and for endogeneity of education when relevant

(Public sector)

Dependent variable: Log hourly earnings

\begin{tabular}{lcc}
\hline Explanatory variables & Brazzaville & Pointe-Noire \\
\hline Education variables & & \\
0-6 years (primary) & -0.041 & 0.023 \\
& $(0.169)$ & $(0.259)$ \\
7-9 years (secondary 1) & 0.054 & $0.283^{* * *}$ \\
10-13 years (secondary 2) & $(0.122)$ & $(0.099)$ \\
& 0.077 & 0.181 \\
13+ years (higher education) & $(0.054)$ & $(0.125)$ \\
& 0.095 & $0.219^{* * *}$ \\
Potential experience & $(0.061)$ & $(0.055)$ \\
& 0.008 & 0.023 \\
(Potential experience) ${ }^{2} / 100$ & $(0.038)$ & $(0.055)$ \\
Tenure in the current employment & 0.010 & -0.011 \\
& $(0.066)$ & $(0.102)$ \\
(Tenure in the current employment) ${ }^{2} / 100$ & 0.008 & 0.024 \\
Woman & $(0.012)$ & $(0.018)$ \\
& -0.022 & -0.045 \\
Urban migrant & $(0.035)$ & $(0.061)$ \\
& 0.054 & -0.260 \\
Rural migrant & $(0.110)$ & $(0.187)$ \\
Inverse of Mill's ratio & 0.032 & 0.006 \\
& $(0.084)$ & $(0.109)$ \\
Education regression residuals & -0.069 & 0.129 \\
& $(0.085)$ & $(0.159)$ \\
Constant & -0.006 & -0.469 \\
Observations & $(0.299)$ & $(0.567)$ \\
Adjusted R-squared & -0.012 & $-0.090^{*}$ \\
& $(0.036)$ & $(0.050)$ \\
& & -3.109 \\
& -0.885 & $(3.094)$ \\
& $(1.510)$ & 214 \\
& & 0.292 \\
\hline
\end{tabular}

Note: Additional explanatory variables introduced in the models are dummies for family situation (single, married monogamous, married polygamous, widow, cohabitation, divorced) and for religion. Standard errors (in parentheses) are estimated using 500 bootstrap replications. *, ** and *** mean coefficient significant at 10 percent, 5 percent and 1 percent, respectively. 
Table A6. Earnings functions with correction for selectivity into sectors and for endogeneity of education when relevant

(Formal private sector)

Dependent variable: Log hourly earnings

\begin{tabular}{|c|c|c|}
\hline Explanatory variables & Brazzaville & Pointe-Noire \\
\hline \multicolumn{3}{|l|}{ Education variables } \\
\hline 0-6 years (primary) & $\begin{array}{l}0.260^{*} \\
(0.138)\end{array}$ & $\begin{array}{c}0.177 \\
(0.118)\end{array}$ \\
\hline 7-9 years (secondary 1 ) & $\begin{array}{l}0.086 \\
(0.136)\end{array}$ & $\begin{array}{c}0.049 \\
(0.072)\end{array}$ \\
\hline $10-13$ years (secondary 2 ) & $\begin{array}{c}0.104 \\
(0.113)\end{array}$ & $\begin{array}{c}0.007 \\
(0.078)\end{array}$ \\
\hline $13+$ years (higher education) & $\begin{array}{c}0.251^{* * *} \\
(0.096)\end{array}$ & $\begin{array}{c}0.063 \\
(0.051)\end{array}$ \\
\hline Potential experience & $\begin{array}{l}-0.035 \\
(0.045)\end{array}$ & $\begin{array}{l}-0.026 \\
(0.031)\end{array}$ \\
\hline$(\text { Potential experience) })^{2} / 100$ & $\begin{array}{c}0.122 \\
(0.109)\end{array}$ & $\begin{array}{c}0.076 \\
(0.058)\end{array}$ \\
\hline Tenure in the current employment & $\begin{array}{c}0.079 * * \\
(0.040)\end{array}$ & $\begin{array}{c}0.008 \\
(0.027)\end{array}$ \\
\hline (Tenure in the current employment) $)^{2} / 100$ & $\begin{array}{l}-0.187 \\
(0.151)\end{array}$ & $\begin{array}{c}0.001 \\
(0.088)\end{array}$ \\
\hline Woman & $\begin{array}{c}0.607 \\
(0.395)\end{array}$ & $\begin{array}{l}-0.044 \\
(0.251)\end{array}$ \\
\hline Urban migrant & $\begin{array}{l}-0.088 \\
(0.292)\end{array}$ & $\begin{array}{c}0.172 \\
(0.166)\end{array}$ \\
\hline Rural migrant & $\begin{array}{c}0.178 \\
(0.269)\end{array}$ & $\begin{array}{l}-0.291 * \\
(0.163)\end{array}$ \\
\hline Inverse of Mill's ratio & $\begin{array}{l}-0.178 \\
(0.594)\end{array}$ & $\begin{array}{c}0.839 \\
(0.539)\end{array}$ \\
\hline Education regression residuals & $\begin{array}{l}-0.043 \\
(0.081)\end{array}$ & \\
\hline Constant & $\begin{array}{c}-3.589 * * \\
(1.565)\end{array}$ & $\begin{array}{l}-0.101 \\
(1.549)\end{array}$ \\
\hline Observations & 140 & 200 \\
\hline Adjusted R-squared & 0.296 & 0.257 \\
\hline
\end{tabular}

Note: Additional explanatory variables introduced in the models are dummies for family situation (single, married monogamous, married polygamous, widow, cohabitation, divorced) and for religion. Standard errors (in parentheses) are estimated using 500 bootstrap replications. ${ }^{*},{ }^{* *}$ and $* * *$ mean coefficient significant at 10 percent, 5 percent and 1 percent, respectively. 
Table A7. Earnings functions with correction for selectivity into sectors and for endogeneity of education when relevant

(Informal sector)

Dependent variable: Log hourly earnings

\begin{tabular}{|c|c|c|}
\hline Explanatory variables & Brazzaville & Pointe-Noire \\
\hline \multicolumn{3}{|l|}{ Education variables } \\
\hline 0-6 years (primary) & $\begin{array}{l}-0.013 \\
(0.047)\end{array}$ & $\begin{array}{c}0.017 \\
(0.040)\end{array}$ \\
\hline 7-9 years (secondary 1 ) & $\begin{array}{c}0.092 * * * \\
(0.035)\end{array}$ & $\begin{array}{c}0.028 \\
(0.034)\end{array}$ \\
\hline $10-13$ years (secondary 2 ) & $\begin{array}{l}-0.007 \\
(0.047)\end{array}$ & $\begin{array}{c}0.087 * * \\
(0.043)\end{array}$ \\
\hline $13+$ years (higher education) & $\begin{array}{c}0.178^{* *} \\
(0.076)\end{array}$ & $\begin{array}{c}0.067 \\
(0.054)\end{array}$ \\
\hline Potential experience & $\begin{array}{c}0.036^{* *} \\
(0.015)\end{array}$ & $\begin{array}{c}0.032 * * \\
(0.015)\end{array}$ \\
\hline$(\text { Potential experience })^{2} / 100$ & $\begin{array}{l}-0.045 \\
(0.027)\end{array}$ & $\begin{array}{l}-0.042 \\
(0.027)\end{array}$ \\
\hline Tenure in the current employment & $\begin{array}{c}0.011 \\
(0.013)\end{array}$ & $\begin{array}{c}0.026^{* *} \\
(0.011)\end{array}$ \\
\hline 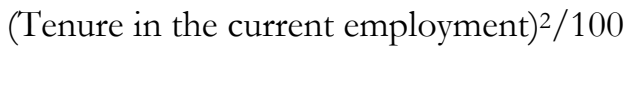 & $\begin{array}{c}0.012 \\
(0.042)\end{array}$ & $\begin{array}{l}-0.052 \\
(0.034)\end{array}$ \\
\hline Woman & $\begin{array}{c}-0.304 * * * \\
(0.085)\end{array}$ & $\begin{array}{c}-0.319^{* * *} \\
(0.079)\end{array}$ \\
\hline Urban migrant & $\begin{array}{l}-0.042 \\
(0.091)\end{array}$ & $\begin{array}{c}0.066 \\
(0.070)\end{array}$ \\
\hline Rural migrant & $\begin{array}{l}-0.112 \\
(0.111)\end{array}$ & $\begin{array}{l}-0.047 \\
(0.073)\end{array}$ \\
\hline Inverse of Mill's ratio & $\begin{array}{l}-0.216 \\
(0.200)\end{array}$ & $\begin{array}{c}-0.393^{* *} \\
(0.154)\end{array}$ \\
\hline Education regression residuals & & $\begin{array}{l}-0.007 \\
(0.027)\end{array}$ \\
\hline Constant & $\begin{array}{c}-1.932 * * * \\
(0.400)\end{array}$ & $\begin{array}{c}-2.128^{* * *} \\
(0.390)\end{array}$ \\
\hline Observations & 807 & 1,103 \\
\hline Adjusted R-squared & 0.0949 & 0.106 \\
\hline
\end{tabular}

Note: Additional explanatory variables introduced in the models are dummies for family situation (single, married monogamous, married polygamous, widow, cohabitation, divorced) and for religion. Standard errors (in parentheses) are estimated using 500 bootstrap replications. *, ** and ${ }^{* * *}$ mean coefficient significant at 10 percent, 5 percent and 1 percent, respectively. 
Table A8. Marginal returns to education using alternative estimation methods

\begin{tabular}{|c|c|c|c|c|c|c|c|c|}
\hline & \multicolumn{2}{|c|}{ All Sectors } & \multicolumn{2}{|c|}{ Public Sector } & \multicolumn{2}{|c|}{ Formal Private Sector } & \multicolumn{2}{|c|}{ Informal Sector } \\
\hline & Brazzaville & $\begin{array}{l}\text { Pointe- } \\
\text { Noire }\end{array}$ & Brazzaville & $\begin{array}{l}\text { Pointe- } \\
\text { Noire }\end{array}$ & Brazzaville & $\begin{array}{l}\text { Pointe- } \\
\text { Noire }\end{array}$ & Brazzaville & $\begin{array}{l}\text { Pointe- } \\
\text { Noire }\end{array}$ \\
\hline & \multicolumn{8}{|c|}{ OLS } \\
\hline \multirow[t]{2}{*}{$0-6$ years (primary) } & 0.007 & 0.017 & -0.057 & -0.188 & $0.238^{*}$ & $0.202^{*}$ & -0.012 & 0.012 \\
\hline & $(0.038)$ & $(0.029)$ & $(0.127)$ & $(0.286)$ & $(0.132)$ & $(0.105)$ & $(0.047)$ & $(0.033)$ \\
\hline \multirow[t]{2}{*}{ 7-9 years (secondary 1$)$} & $0.092 * * *$ & $0.033^{*}$ & 0.042 & $0.161 * *$ & 0.032 & 0.055 & $0.100 * * *$ & 0.020 \\
\hline & $(0.024)$ & $(0.019)$ & $(0.051)$ & $(0.062)$ & $(0.095)$ & $(0.060)$ & $(0.030)$ & $(0.022)$ \\
\hline \multirow[t]{2}{*}{$10-13$ years (secondary 2 ) } & $0.054^{* *}$ & $0.094 * * *$ & $0.066^{* *}$ & 0.014 & 0.059 & $0.118^{*}$ & 0.009 & $0.105^{* * *}$ \\
\hline & $(0.027)$ & $(0.024)$ & $(0.032)$ & $(0.046)$ & $(0.086)$ & $(0.061)$ & $(0.045)$ & $(0.032)$ \\
\hline \multirow[t]{3}{*}{$13+$ years (higher education) } & $0.117 * * *$ & $0.088^{* * *}$ & $0.082 * * *$ & $0.110^{* * *}$ & $0.208^{* * *}$ & 0.069 & $0.200 * * *$ & $0.070^{*}$ \\
\hline & $(0.020)$ & $(0.023)$ & $(0.018)$ & $(0.032)$ & $(0.062)$ & $(0.043)$ & $(0.061)$ & $(0.039)$ \\
\hline & \multicolumn{8}{|c|}{ Selectivity corrected (Heckman method) } \\
\hline \multirow[t]{2}{*}{$0-6$ years (primary) } & 0.006 & 0.018 & -0.057 & -0.067 & $0.229 *$ & 0.177 & -0.013 & 0.010 \\
\hline & $(0.045)$ & $(0.030)$ & $(0.141)$ & $(0.267)$ & $(0.133)$ & $(0.118)$ & $(0.047)$ & $(0.031)$ \\
\hline \multirow[t]{2}{*}{ 7-9 years (secondary 1 ) } & $0.093^{* * *}$ & $0.039 * *$ & 0.043 & $0.212^{* *}$ & 0.041 & 0.049 & $0.092^{* * *}$ & 0.022 \\
\hline & $(0.029)$ & $(0.019)$ & $(0.108)$ & $(0.085)$ & $(0.111)$ & $(0.072)$ & $(0.035)$ & $(0.021)$ \\
\hline \multirow{2}{*}{$10-13$ years (secondary 2 ) } & $0.054^{* *}$ & $0.107 * * *$ & $0.067 * *$ & 0.102 & 0.062 & 0.007 & -0.007 & $0.081^{* *}$ \\
\hline & $(0.025)$ & $(0.024)$ & $(0.034)$ & $(0.115)$ & $(0.085)$ & $(0.078)$ & $(0.047)$ & $(0.037)$ \\
\hline \multirow[t]{3}{*}{$13+$ years (higher education) } & $0.119 * * *$ & $0.091 * * *$ & $0.082^{* *}$ & $0.129 * * *$ & $0.209 * * *$ & 0.063 & $0.178^{* *}$ & 0.060 \\
\hline & $(0.021)$ & $(0.026)$ & $(0.035)$ & $(0.036)$ & $(0.052)$ & $(0.051)$ & $(0.076)$ & $(0.049)$ \\
\hline & \multicolumn{8}{|c|}{ Selectivity corrected + father education and occupation in earnings functions } \\
\hline \multirow[t]{2}{*}{$0-6$ years (primary) } & 0.006 & 0.012 & -0.063 & -0.063 & 0.232 & 0.116 & -0.012 & 0.004 \\
\hline & $(0.042)$ & $(0.030)$ & $(0.146)$ & $(0.156)$ & $(0.144)$ & $(0.111)$ & $(0.050)$ & $(0.033)$ \\
\hline \multirow[t]{2}{*}{$7-9$ years (secondary 1$)$} & $0.088^{* * *}$ & $0.037^{* *}$ & 0.047 & 0.047 & 0.024 & 0.072 & $0.084^{* *}$ & 0.024 \\
\hline & $(0.028)$ & $(0.019)$ & $(0.109)$ & $(0.102)$ & $(0.118)$ & $(0.071)$ & $(0.034)$ & $(0.023)$ \\
\hline \multirow[t]{2}{*}{$10-13$ years (secondary 2) } & $0.054^{* *}$ & $0.101 * * *$ & $0.066^{*}$ & $0.066^{*}$ & 0.065 & -0.011 & 0.004 & $0.081 * *$ \\
\hline & $(0.025)$ & $(0.026)$ & $(0.034)$ & $(0.036)$ & $(0.077)$ & $(0.100)$ & $(0.045)$ & $(0.036)$ \\
\hline
\end{tabular}




\begin{tabular}{|c|c|c|c|c|c|c|c|c|}
\hline 13 years + (higher education) & $\begin{array}{c}0.115^{* * *} \\
(0.020)\end{array}$ & $\begin{array}{c}0.091 * * * \\
(0.026)\end{array}$ & $\begin{array}{c}0.085^{* *} \\
(0.038)\end{array}$ & $\begin{array}{c}0.085^{* *} \\
(0.037)\end{array}$ & $\begin{array}{c}0.178 * * * \\
(0.064)\end{array}$ & $\begin{array}{c}0.059 \\
(0.047)\end{array}$ & $\begin{array}{c}0.189 * * \\
(0.080)\end{array}$ & $\begin{array}{c}0.070 \\
(0.050)\end{array}$ \\
\hline & \multicolumn{8}{|c|}{ Selectivity corrected + Control function (FC) } \\
\hline \multirow[t]{2}{*}{$0-6$ years (primary) } & & 0.055 & -0.041 & 0.023 & $0.260^{*}$ & & & 0.017 \\
\hline & & $(0.037)$ & $(0.169)$ & $(0.259)$ & $(0.138)$ & & & $(0.040)$ \\
\hline \multirow[t]{2}{*}{ 7-9 years (secondary 1 ) } & & $0.075^{* * *}$ & 0.054 & $0.283^{* * *}$ & 0.086 & & & 0.028 \\
\hline & & $(0.028)$ & $(0.122)$ & $(0.099)$ & $(0.136)$ & & & $(0.034)$ \\
\hline \multirow[t]{2}{*}{$10-13$ years (secondary 2 ) } & & $0.142^{* * *}$ & 0.077 & 0.181 & 0.104 & & & $0.087^{* *}$ \\
\hline & & $(0.032)$ & $(0.054)$ & $(0.125)$ & $(0.113)$ & & & $(0.043)$ \\
\hline \multirow[t]{2}{*}{$13+$ years (higher education) } & & $0.130^{* * *}$ & 0.095 & $0.219^{* * *}$ & $0.251 * * *$ & & & 0.067 \\
\hline & & $(0.033)$ & $(0.061)$ & $(0.055)$ & $(0.096)$ & & & $(0.054)$ \\
\hline
\end{tabular}

Note: The explanatory variables reported in Tables A4 to A7 are included. *, ** and $* * *$ mean coefficient significant at 10 percent, 5 percent and 1 percent, respectively. The highlighted coefficients are those at the mean value of education level in the considered city and sector. These highlighted coefficients were used to graph Figure 1. 
Table A9. Tests of crossed gender effects with education

Dependent variable: Log hourly earnings

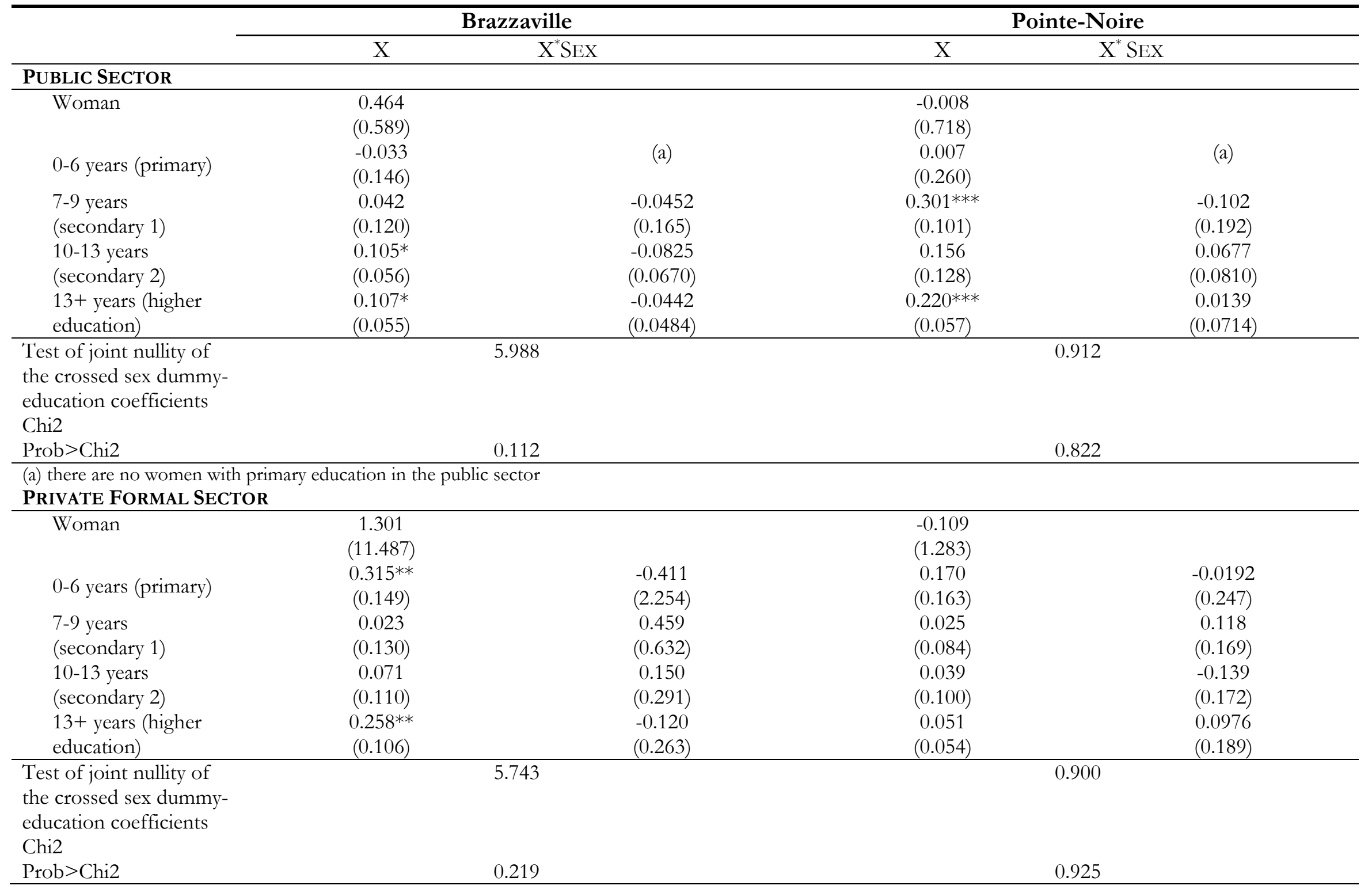




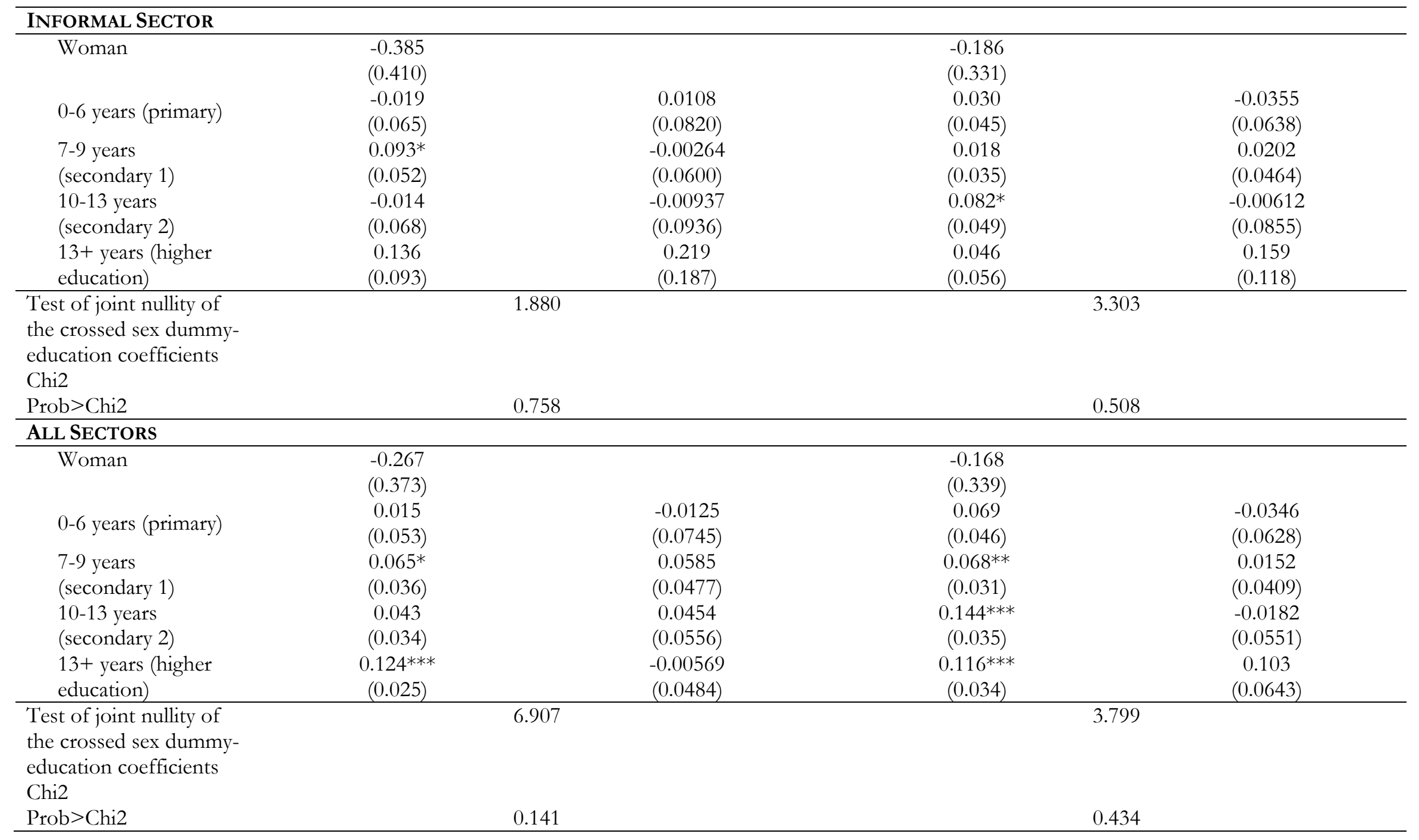

Note: SEX is a dummy indicating a woman. Additional explanatory variables introduced in the models are dummies for family situation (single, married monogamous, married polygamous, widow, cohabitation, divorced) and for religion. Standard errors (in parentheses) are estimated using 500 bootstrap replications. *,** and $* * *$ mean coefficient significant at 10 percent, 5 percent and 1 percent, respectively. 
Table A10. Tests of crossed age effects with education

Dependent variable: Log hourly earnings

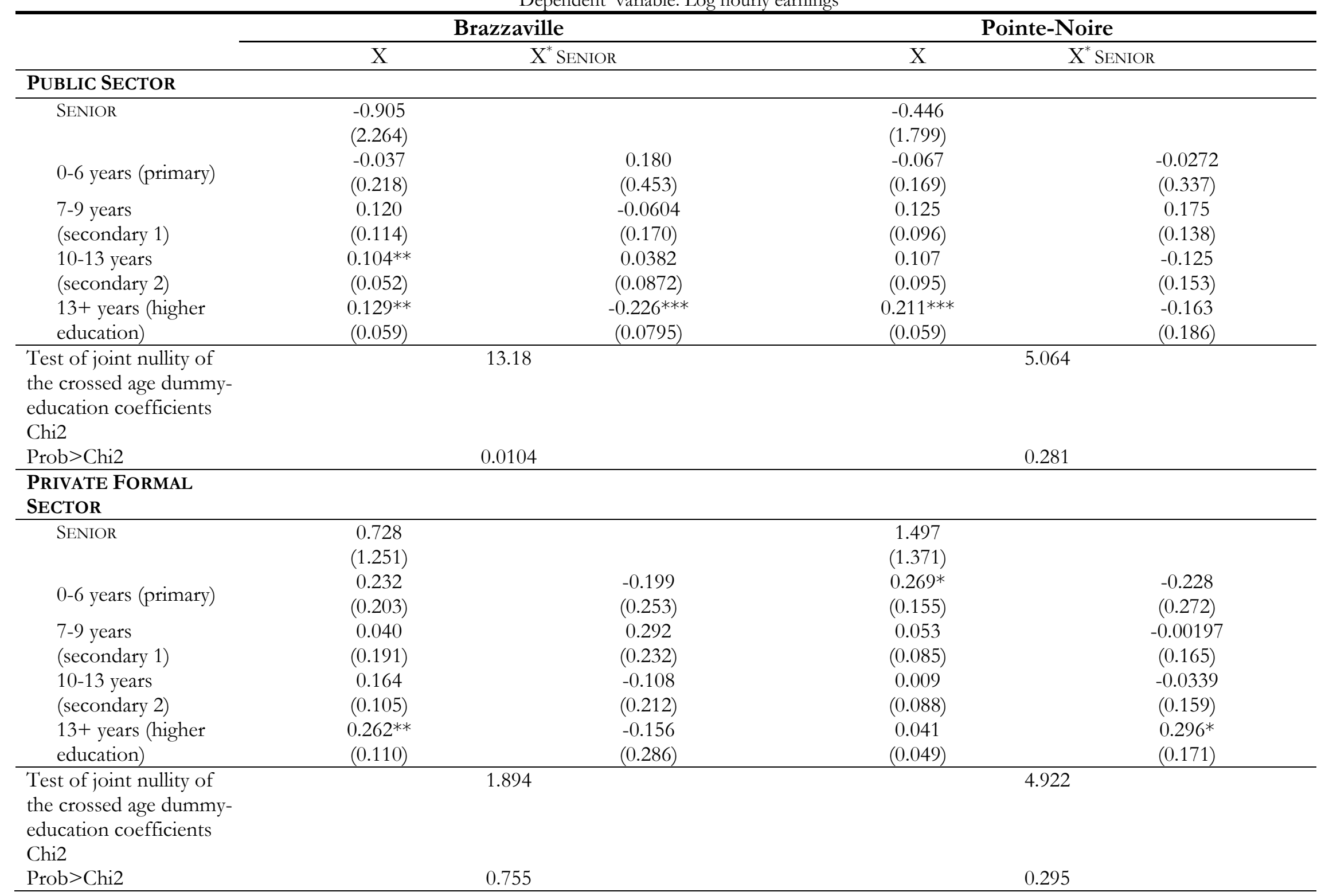




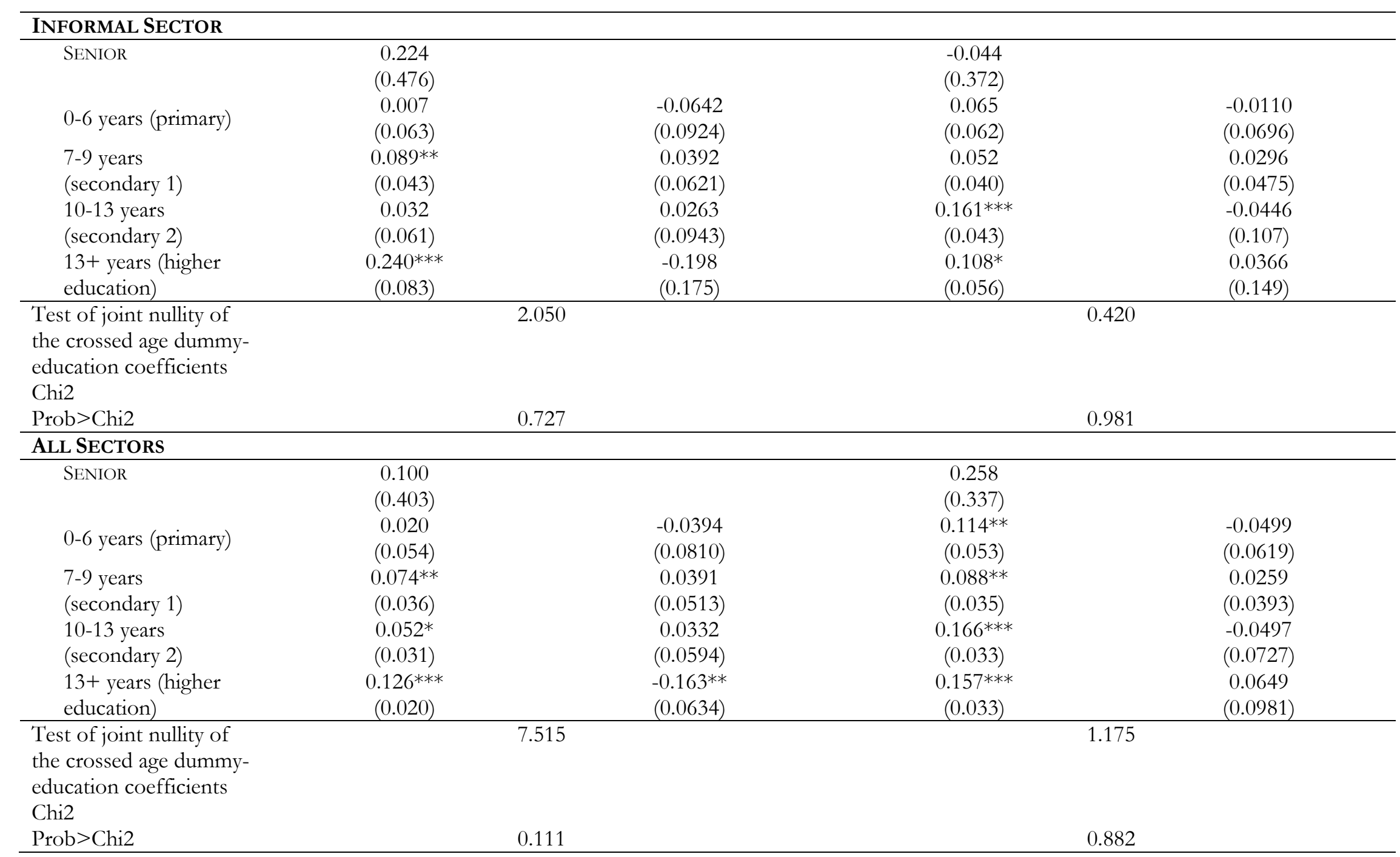

Note: SENIOR is a dummy indicating whether the individuals are 30 years old or above. Additional explanatory variables introduced in the models are dummies for family situation (single, married monogamous, married polygamous, widow, cohabitation, divorced) and for religion. Standard errors (in parentheses) are estimated using 500 bootstrap replications. $*$,** and $* * *$ mean coefficient significant at 10 percent, 5 percent and 1 percent, respectively. 


\section{APPENDIX B. ECONOMETRIC METHODS}

\section{B.1 Earnings equation with correction of the selection bias}

In this study, we jointly model earning equations and selection into differents sectors as follows:

$S_{i j}^{*}=\beta_{j}^{\prime} X_{i}+\varepsilon_{i j}$

and

$Y_{i j}=\zeta_{j}^{\prime} Z_{i}+\eta_{i j}$

where $Y_{i j}$ represents the compensation received by individual $i$ who works in sector $j$, with $j=0$ (not working); $j=1$ (public sector), 2 (formal sector) or 3 (informal sector). By definition, $Y_{i 0}$ (a kind of reservation wage) is unknown, but $S_{i 0}$ (not working or no compensation) is known and used in the first-stage estimations. $Z_{i}$ is the vector for the individual's observable characteristics, including education, $\zeta_{j}$ is a vector of parameters to be estimated, and $\eta_{i j}$ an error term. We estimate each sector's coefficients $\zeta_{j} . Y_{j}$ is only observed if the sector $j$ is selected, therefore $\eta_{j}$ and $\varepsilon_{j}$ are not independent. This means that the assigning mechanism in each category is not random, and has a significant effect on earnings.

In regression (1), we use multinomial logit models to compute the correction terms $\lambda_{i j}$, based on the expected probability that individual $i$ be in sector $j$ or not working. The generalized pattern of the inverse Mills ratio is then introduced in the income equation for each sector $j$ and provides unbiased estimates of $\beta_{j}$. $\lambda_{i j}$ can be estimated with different methods: Lee's, McFadden's or Dahl's. Lee's correction method has been debated because it is based on strong restrictions related to the joint distribution of the error terms in the equations of interest (Vijverberg, 1993 ; Dahl, 2002 ; Bourguignon et al., 2007). However, the other methods we have tried, such as Dubin's and McFadden's or Dahl's, did not appear more effective given the small size of our sectoral subsamples ${ }^{11}$. Therefore, we selected Lee's correction method (cf. Lee, 1983).

In both Heckman's and Lee's procedures, identification is achieved using exclusion restrictions. In each sector, we use six dummy variables that describe the relationship of an individual to the head of household (child, spouse, etc.). The rationale behind this identification strategy is that, all else being equal, the relationship to the household head may only influence the level of individual earnings through its effect on sector choice and allocation (including the not working category). We tested the relevance of this identification strategy using Wald's tests of joint significance of the identifying variables in the first regression, and by testing their insignificance in the second regressions, for each sector. The results confirmed this was an appropriate choice in all cases ${ }^{12}$. However, keeping in mind methodological controversies regarding the selection of identifying variables in general, we also report overall results from the uncorrected earnings function (OLS), in order to provide results which are comparable to some existing studies.

\footnotetext{
11 Indeed, based on Monte-Carlo simulations, Bourguignon et al. (2007) find that Lee's method is well adapted to small samples.

12 For both cities and all sectors, Wald's joint significance tests on instruments used in the first step never rejected the null hypothesis at the 1 percent threshold. Note that the second equation remains identified even without the exclusion condition for the purpose of the tests, since identification then relies on the distributional hypothesis in Lee's model (see Bourguignon et al., 2007). Coefficients of the dummies of relation to the household head are reported in Tables A2 and A3 in Appendix A.
} 


\section{B.2 Endogeneity of education}

Education can be an endogenous variable in earnings equations if it is correlated to the error term of the equation, either because there is unobserved individual heterogeneity or measurement errors in the education variable.

To solve the issue of endogeneity, one typically uses instrumental variable methods which require variables that are not correlated to the unobserved heterogeneity of individuals, but to their education. Instrumentation often relies on households and demographic characteristics assumed to not be correlated to the error term of the income equation. This strategy is widely used with data on developing countries and can capture various environmental influences. Thus, Ashenfelter and Zimmerman (1997) use parental education as instrument, Butcher and Case (1994) employ the presence of a sister in the family, and Card (1995) relies on geographic proximity to a junior high school.

In this paper, we address this issue using the father's educational level and professional status as instruments (see Table A1 in Appendix A for the definition and descriptive statistics of these variables), and we adopt a control function (CF) approach (Wooldridge, 2002). Family background variables are generally believed to be strong instruments in developing countries, as they capture various genetic and environment influences (Sahn and Alderman, 1988). However, one could argue that the father's education and job professional status may not respect the exclusion restriction condition, in the sense that these may have a direct effect on children's labour market achievements, perhaps through family wealth or preference for jobs in a particular labour market segment. Recently, Hoogerheide et al. (2012) show using panel data and bayesian analysis that, even if there is a violation of the strict validity assumption, parental characteristics (in their study, this is father's education) used as instruments of children's education still yield acceptable estimates because their effect on children's education is generally larger ("strong") than their direct effect on the children's labour market outcomes. This finding provides confidence in the use of father's characteristics as instruments in earnings equations.

The method that uses the CF is adapted when the income/education profile is non-linear in the estimated parameters. As our results show, education's marginal effect on income is not constant. The empirical implementation of the CF consists, first of all, in running the first-stage equation like in a traditional IV approach. Then we recover the estimated residuals and use them as an additional explanatory variable in the second-stage equation, together with the education variables. Following Blackburn and Neumark (1995), Lam and Schoeni (1993), or Ashenfelter and Zimmerman (1997), we also made a different use of family background information by introducing it directly into the earnings functions. Applying all these different techniques is interesting because the various underlying hypotheses can reveal common trends in the results, which must then be seen as being relatively robust. In turn, even if issues of endogeneity are not perfectly corrected, the similarity of results from different methods should convince us of their relative robustness. 


\section{References}

Aromolaran, A. B., 2006, "Estimates of Mincerian Returns to Schooling in Nigeria", Oxford Development Studies 34(2), p. 265-292.

Ashenfelter, O., Zimmerman, D., 1997, "Estimating of Return to Schooling from Sibling Data: Fathers, Sons and Brothers", Review of Economics and Statistics 79, p. 1-9.

Backiny-Yetna, P., Wodon Q., 2010, "Gender Labor Income Shares and Human Capital Investment in the Republic of Congo", in Gender Disparities in Africa's Labor Market, Arbache J.S. et al. (Eds), Chapter 10, Africa Development Forum Series, Washington DC: The World Bank, p. 359.

Bennell, P., 1996, "Rates of Return on Education: Does the Conventional Pattern Prevail in SubSaharan Africa?", World Development 24 (1), p. 183-199.

Blackburn, M., Neumark, D., 1995, “Are OLS Estimates of the Return to Schooling biased downward? Another Look", Review of Economics and Statistics 77, p. 217-229.

Bocquier, P., Nordman, C.J., Vescovo, A., 2010, "Employment Vulnerability and Earnings in Urban West Africa", World Development 38 (9), p. 1297-1314.

Bourguignon, F., Fournier, M., Gurgand, M., 2007, "Selection Bias Corrections based on the Multinomial Logit Model: Monte-Carlo Comparisons", Journal of Economic Surveys 21 (1), p. 174-205.

Butcher, K.F., Case, A., 1994, “The Effects of Sibling Composition on Women's Education and Earnings", Quarterly Journal of Economics 109, p. 443-450.

Card, D., 1995, "Using Geographic Variation in College Proximity to Estimate the Return to Schooling”, in Christofides, L.N., Grant, E.K., Swidinsky, R. (dir.), Aspects of Labour Market Behavior: Essays in Honor of John V anderkamp, University of Toronto, Canada), p. 201-222.

Card, D., 2001, "Estimating the Return to Schooling: Progress on Some Persistent Econometric Problems", Econometrica 69, p. 1127-1160.

CNSEE, 2006, ECOM-2005, Congo Poverty Assessment Household Survey. Poverty Profile in the Congo in 2005. Final Analysis Report, 141 p.

CNSEE, 2009, 1-2 Survey. Phase 1: Employment Survey. Pollster Manual, 30 p.

CONFEMEN \& MEPSA, 2009, PASEC Republic of Congo Report 2009. Primary Education in the Congo: Seeking Quality and Equity, $151 \mathrm{p}$.

Dahl, G., 2002, "Mobility and the Returns to Education: Testing a Roy Model with Multiple Markets", Econometrica 70, p. 2367-2420.

Dimova, R., Nordman, C.J., Roubaud, F., 2010, "Allocation of Labor in Urban West Africa: Insights from the Pattern of Labor Supply and Skill Premium", Review of Development Economics 14 (1), p. 160-178.

Foltz, J.D., Gajigo, O., 2012, “Assessing the Returns to Education in the Gambia”, Journal of African Economies 21(4), p. 580-608.

Hoogerheide, L., Block, J.H., Thurik R., 2012. Family Background Variables as Instruments for Education in Income Regressions: A Bayesian Analysis. Economics of Education Review 31, p. $515-523$.

Jolliffe, D., 2004, "The Impact of Education in Rural Ghana: Examining Household Labor Allocation and Returns On and Off the Farm", Journal of Development Economics 73(1), p. 287314.

Kouamé, A., 1999, Women's Education and Employment in Abidjan, l'Harmattan, Collection Sociétés Africaines et Diaspora. 
Kuépié, M., Nordman, C.J., Roubaud, F. 2009, "Education and Earnings in Urban West Africa", Journal of Comparative Economics 37 (3), p. 491-515.

Kuépié, M., Nordman, C.J. 2011, "Éducation et marchés du travail à Brazzaville et Pointe Noire (Congo-Brazzaville)", Background Paper for the Employment and Growth Study for the Republic of Congo, The World Bank; DIAL Research Paper DT/2011/11 (in French).

Lam, D., Schoeni, R.F., 1993, "Effects of Family Background on Earnings and Returns to Schooling: Evidence from Brazil”, Journal of Political Economy 1001, p. 710-740.

Lee, L.-F., 1983, “Generalized Econometric Models with Selectivity”, Econometrica 51 (2), p. 507512.

Nordman, C.J., Robilliard, A.-S., Roubaud, F., 2011, “Gender and Ethnic Earnings Gaps in Seven West African Cities”, Labour Economics, 18 Supplement 1, p. S132-S145.

Nordman, C.J., Roubaud, F., 2010, “An Original Approach in Development Economics: 20 Years of Work on Measuring and Analyzing the Informal Economy in Developing Countries", Dialogue, 31, October, DIAL: Paris.

Oyelere, R.U., 2011, "Have Returns to Education Changed in Nigeria? Uncovering the Role of Democratic Reforms", Journal of African Economies 20(5), p. 737-780.

Ray, D., 1998, Development Economics, New Jersey : Princeton University Press.

Razafindrakoto, M., Roubaud, F., Torelli, C., 2009, "Measuring Employment and Informal Sectors: Lessons from the 1-2-3 surveys in Africa", Stateco 104, p. 11-34.

Roubaud, F., Torelli, C., 2013, "Employment, Unemployment, and Working Conditions in the Urban Labor Markets of Sub-Saharan Africa: Main Stylized Facts", in Urban Labour Markets in Sub-Saharan Africa, De Vreyer, Ph. and Roubaud, Fr. (Eds), Washington: The World Bank - Agence Française de Développement, Chapter 1, p. 37-80.

Sahn, D.E., Alderman, H., 1988, “The Effects of Human Capital on Wages and the Determinants of Labor Supply in a Developing Country," Journal of Development Economics 29, p. 157-183.

Schultz, T.P., 2002, "Why Governments Should Invest More to Educate Girls", World Development 30 (2), p. 207-225.

Schultz, T.P., 2004, "Evidence of Returns to Schooling in Africa from Household Surveys: Monitoring and Restructuring the Market for Education", Journal of African Economies 13, AERC Supplement, p. ii95-ii148.

Shapiro, D., Oleko B.T., 2001, “Gender, Poverty, Family Structure, and Investments in Children's Education in Kinshasa, Congo", Economics of Education Review 20(4), p. 359-375.

Siphambe, H. K., 2000, "Rates of Return to Education in Botswana", Economics of Education Review 19(3), p. 291-300.

Söderbom, M., Teal, F., Wambugu, A., Kahyarara, G., 2006, "Dynamics of Returns to Education in Kenyan and Tanzanian Manufacturing", Oxford Bulletin of Economics and Statistics 68 (3), p. 261-288.

UNESCO/Breda, 2007, "Education for All in Africa 2007: Top Priorities for Integrated SectorWide Policies", Dakar+7, ISBN 978-92-9091-095-4, the Dakar Hub.

Vijverberg, W.P., 1993, "Educational Investments and Returns for Women and Men in Côte d'lvoire", Journal of Human Resources 28 (4), p. 933-974.

Vijverberg, W.P., 1995, "Returns to Schooling in Non-Farm Self-Employment: An Econometric Case Study of Ghana”, World Development 23 (7), p. 1215-1227.

Wooldridge, J.M., 2002, "Unobserved Heterogeneity and Estimation of Average Partial Effects", Michigan State University Working Paper. 